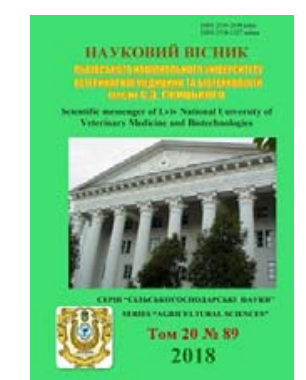

Науковий вісник Дьвівського національного університету
ветеринарної медицини та біотехнологій імені С.3. Гжицького

\author{
Scientific Messenger of Lviv National University \\ of Veterinary Medicine and Biotechnologies
}

UDC 633.15:579.852.11

\title{
The effectiveness of the use of probiotics for wet maize grain preserving
}

\author{
N. Fedak ${ }^{1}$, S. Chumachenko ${ }^{1}$, L. Darmohray ${ }^{2}$, B. Gutyj ${ }^{2}$, M.H. Perederiy ${ }^{3}$ \\ ${ }^{1}$ Institute of Agriculture of Carpathian Region of Ukraine NAAS, Obroshino, Ukraine \\ ${ }^{2}$ Stepan Gzhytskyi National University of Veterinary Medicine and Biotechnologies Lviv, Ukraine \\ ${ }^{3}$ Institute of Agricultural Microbiology and agro-industrial production of NAAS, Chernihiv, Ukraine
}

\section{Article info}

Received 14.09.2018 Received in revised form 17.10 .2018

Accepted 18.10.2018

Institute of Agriculture of Carpathian region of Ukraine, NAAS of Ukraine, Grushevskogo Str., 5, Obroshino, 81115, Ukraine.

Tel.: +38-050-975-05-67 E-mail: natalifedak@i.ua

Stepan Gzhytskyi National University of Veterinary Medicine and Biotechnologies Lviv, Pekarska Str., 50, Lviv, 79010, Ukraine.

Institute of Agricultural Microbiology and agro-industrial production of NAAS, Shevchenko Str., 97, Chernihiv, 14027, Ukraine.
Fedak, N., Chumachenko, S., Darmohray, L.M., Gutyj, B.V., \& Perederiy, M.H. (2018). The effectiveness of the use of probiotics for wet maize grain preserving. Scientific Messenger of Lviv National University of Veterinary Medicine and Biotechnologies, 20(89), 85-88. doi: $10.32718 /$ nvlvet8916

The process of processing and storage of high moisture grain is one of the important problems of forage production, especially in the Carpathian region due to its excessive moisture, therefore, due to the intensification of the livestock industry, the conservation of feed is becoming increasingly important. The purpose of the research was to determine the effect of different doses of bacterial preparation KT-L 18/1 (produced by Chernihiv ISMAV NAAS) on the preservation of nutrients and microbiological parameters of maize grain of high humidity in dynamics. The investigation of influence different doses of bacterial preparation KT-L 18/1 on the nutrients and microbiological parameters protection in maize grain with high humidity were realized in the laboratory of animal feed and feed technology (containers with maize grain, treated with different doses of microbial preparation KT-L 18/1, were laid, their chemical composition and microbiological parameters were determined). The control was grain without drying and with the addition of a chemical preservative CAS. During storage of treated maize grain were determined their chemical composition, content of main fermentation acids, and microbiological parameters. It was found that dry matter reduce, an integral feed nutrition indicator, in maize grain samples, treated with KT-L-18/1 and chemical preservative were 1.0 and $1.1 \%$ respectively. The lowest number of harmful micromycetes was noted by using the KT-L-18/1 at dose $8 \mathrm{ml} / \mathrm{kg}$. It was found that using of chemical preservative CAS suppresses all investigated microorganisms, including lactic acid bacteria. Probiotic preparation KT-L-18/1 at dose $8 \mathrm{ml} / \mathrm{kg}$ wet maize grain provides to nutrients preservation same level like chemical preservative through active development of lactic acid microorganisms. It is advisable for final conclusions to carry out the testing of this preparation during the harvesting of wet ivy corn grain under production conditions and in experiments on animals

Key words: maize, grain, humidity, probiotics, dry matter, nutrition.

\section{Ефективність застосування пробіотиків при консервуванні вологого зерна кукурудзи}

\author{
Н.М. Федак ${ }^{1}$ С.П. Чумаченко ${ }^{1}$, Л.М. Дармограйㄹ, Б.В. Гутий², М.Г. Передерій \\ ${ }^{1}$ Інститут сільського господарства Карпатського регіону Украӥни НААН, с. Оброшино, Украӥна \\ ${ }^{2}$ Львівський національний університет ветеринарної медищини та біотехнологій імені С. 3. Гжицького, \\ м. Львів, Україна \\ ${ }^{3}$ Чернігівський інститут сільськогосподарської мікробіологї̈ АПВ, м. Чернігів, Україна
}

Дослідження щуодо визначення впливу різних доз бактеріального препарату КT-L 18/1 на збереженість поживних речовин та мікробіологічні показники зерна кукурудзи підвищеної вологості в динаміці проведено у лабораторії годівлі тварин і технології кормів (закладка в ємкостях зерна кукурудзи, обробленого різними дозами мікробного препарату KT-L 18/1, визначення його хімічного складу та мікробіологічних показників). Контролем слугували варіанти без сушіння та з внесенням хімічного консерванту (ВАС). У прочесі зберігання у консервованих зразках плющеної кукурудзи визначали хімічний склад, вміст основних кислот бродіння та заплановані мікробіологічні показники. Встановлено, щзо втрати сухої речовини як інтегрального показника поживності корму 
у зразках плющеного зерна кукурудзи, обробленого препаратами KT-L-18/1 та ВАС у граничних дозах, становили відповідно 1,0 та 1,1 відн. \%. Найнижчу чисельність найбільш шкодочинних мікроміцетів відзначено у варіанті з використанням препарату КT-L18/1 у дозі 8 мл/кг. Досліджено, щчо використання ВАС забезпечує пригнічення практично всіх досліджуваних мікроорганізмів, у m. ч. і найбільш корисних молочнокислих бактерій. Пробіотичний препарат KT-L-18/1 в дозі 8 мл/кг вологого зерна кукурудзи забезпечує збереженість його поживних речовин практично на рівні з хімічним консервантом завдяки активному розвитку молочнокислих мікроорганізмів.

Ключові слова: кукурудза, зерно, вологість, пробіотики, суха речовина, поживність.

Вступ

Переробка та зберігання зернофуражу підвищеної вологості є однією з важливих проблем кормовиробництва, особливо в Карпатському регіоні з огляду на його надмірну зволоженість, тому у зв'язку з інтенсифікацією тваринницької галузі консервування кормів набуває все більшого значення. Розробка нових технологічних прийомів консервування зерна підвищеної вологості, пошук консервантів біологічної природи є актуальним, особливо для практики кормовиробництва та годівлі сільськогосподарських тварин у Карпатському регіоні (Konyukhov et al., 2004; Hlushko, 2006; Kulyk, 2006; Darmohray et al., 2017; Kashirskaja et al., 2017; Gutyj et al., 2017; Darmohray et al., 2018).

Метою наших досліджень було встановити вплив різних доз бактеріального препарату KT-L 18/1 (виробництва Чернігівського ICMAB НАAН) на збереженість поживних речовин та мікробіологічні показники зерна кукурудзи підвищеної вологості в динаміці.

\section{Матеріал та методи досліджень}

Дослідження проведено у лабораторії годівлі тварин і технології кормів Інституту сільського господарства Карпатського регіону НААН. Зразки вологого зерна кукурудзи (30,2\%), обробленого різними дозами (4 і 8 мл/кг зерна) мікробного препарату KT-L 18/1, закладали в скляні ємкості та зберігали в лабораторних умовах у затемненому місці. Контролем слугували варіанти без обробки та 3 внесенням хімічного консерванту ВАС (вуглеамонійної солі).

У процесі зберігання через 5, 15, 30 та 70 діб у зразках плющеної кукурудзи визначали хімічний склад (Vudmaska and Prylutskyy, 1975) та через 5, 15, 30 діб зберігання провели дослідження кількісного складу мікрофлори за загальноприйнятими мікробіологічними методами (Tepper et al., 2004; Solyanyk and Hlaskovych, 2014) за схемою, наведеною в табл.1.

Вміст основних кислот бродіння визначали методом Леппер-Фліга згідно з вимогами ГОСТ 23638-79.

\section{Таблиця 1}

Схема мікробіологічних досліджень

\begin{tabular}{cccc}
\hline Мікроорганізми & \multirow{2}{*}{ Живильне середовище } & Температура & \multicolumn{2}{c}{ Час інкубування, } \\
інб
\end{tabular}

\section{Результати та їх обговорення}

Хімічний склад досліджуваних зразків плющеного зерна кукурудзи в динаміці наведено в табл. 2.

При порівняльному аналізі хімічного складу зразків контрольного та дослідних варіантів плющеного вологого зерна кукурудзи було встановлено, що втрати поживних речовин на 70 добу консервування за обробки сировини препаратом KT-L 18/1 (3-4 варіанти) становили відповідно 1,0 та 1,3 відн.\%.

У варіанті без консерванту втрати поживності за сухою речовиною у кормі були найбільшими та складали $1,8 \%$. Разом $з$ тим збереженість поживних речовин у плющеному зерні кукурудзи за сирим протеїном у дослідних варіантах з бактеріями і в контрольному варіанті 3 хімічним консервантом була вища, ніж у вихідній сировині - вже на 5 добу консервування та на 70 добу консервування переважала вихідні показники на $0,25 \%$ і 0,3\% відповідно. У контрольному варіанті без консерванту цей показник навіть дещо зменшився (Suslova, 2012).

Одним із інтегральних показників при оцінці консервуючої здатності пробіотичних препаратів $\epsilon$ вміст та співвідношення основних кислот бродіння у зразках зернофуражу (табл. 3).

Визначальними чинниками, що впливають на якість консервування вологого плющеного зерна кукурудзи, $\epsilon$ процеси мікробіологічного бродіння (Kvasnykov and Nesterenko, 1975; Tepper et al., 2004; Solyanyk and Hlaskovych, 2014; Nekrashevich et al., 2017), результати яких наведено в табл. 4.

При аналізі результатів 3 вивчення впливу пробіотиків на мікрофлору плющеної кукурудзи було встановлено, що вже на початку другої мікробіологічної фази у видовому складі мікрофлори плющеної кукурудзи переважають молочнокислі бактерії як у дослідних, так і в контрольних варіантах (Derevyanko, 2009; Volkohon, 2015; Darmohray and Gonchar, 2015). 
Проте у варіантах 3 препаратом KT-L 18/1 їх чисельність найвища, а за бурхливого розвитку молочнокислих бактерій фіксується найбільше пригнічення росту чисельності маслянокислих бактерій та плісеневих грибів.

Спостерігається пригнічення росту та розвитку усіх груп бактерій, у тому числі й молочнокислих, у контрольному варіанті 3 застосуванням хімічного консерванту ВАС. Разом 3 тим із початком третьої мікробіологічної фази з'явилася тенденція до зниження чисельності молочнокислих бактерій у всіх варіантах, що цілком закономірно через накопичення високої концентрації молочної кислоти, кількість якої щодо суми органічних кислот у зразках складала від 76,9\% у контрольному варіанті без застосування консерванту - до 94,35\% у 4 дослідному варіанті з пробіотиком KT-L 18/1. На цьому етапі дозрівання консервованого плющеного вологого зерна кукурудзи важливою умовою для одержання якісного корму є чисельність грибів та дріжджів, за розвитку яких спостерігається виникнення аеробного псування корму (Kravchenko et al., 2017). В результаті мікробіологічного аналізу було встановлено, що найнижча чисельність грибів та дріжджів спостерігалась у 4 дослідному варіанті консервованого корму.

Таблиця 2

Хімічний склад зразків плющеного зерна кукурудзи, \%

\begin{tabular}{|c|c|c|c|c|c|c|c|c|c|c|c|c|c|c|c|c|c|}
\hline \multirow{3}{*}{ Показники } & \multirow{3}{*}{$\begin{array}{l}\text { Вихідна } \\
\text { сировина }\end{array}$} & \multicolumn{4}{|c|}{ Контроль } & \multicolumn{3}{|c|}{ BAC } & \multicolumn{5}{|c|}{ KТ-L 18/1 (4 мл) } & \multicolumn{4}{|c|}{ KТ-L 18/1 (8 мл) } \\
\hline & & \multicolumn{16}{|c|}{ Доба } \\
\hline & & 5 & 15 & 30 & 70 & 5 & 15 & 30 & 70 & 5 & 15 & 30 & 70 & 5 & 15 & 30 & 70 \\
\hline & & 30,1 & 30,4 & 30,7 & 31,4 & 29,7 & 30,0 & 30,6 & 30,9 & 30,3 & 30,5 & 30,5 & 30,9 & 30,5 & 30,5 & 30,7 & 31,1 \\
\hline & & 69,9 & 69,6 & 69,3 & 68,6 & 70,3 & 70,0 & 69,4 & 69,1 & 69,7 & 69,5 & 69,5 & & 9,5 & 69,5 & 69,3 & \\
\hline & & 7,02 & 7,03 & 7,05 & 7,00 & 7,31 & 7,37 & 7,40 & 7,35 & 7,00 & 7,10 & 7,24 & & 7,15 & 7,14 & 7,20 & 7,31 \\
\hline ир & & 2,15 & 2,14 & 2,15 & 2,12 & 2,12 & 2,12 & 2,12 & 2,10 & 2,10 & 2,11 & 2,13 & 2,13 & 2,10 & 2,09 & 2,11 & 2,14 \\
\hline ира & 2,01 & 2,11 & 2,13 & 2,16 & 2,48 & 2,00 & 2,05 & 2,12 & 1,78 & 2,00 & 2,07 & 2,09 & 2,47 & 2,02 & 2,05 & 2,10 & 1,91 \\
\hline${ }^{\mathrm{P}} \mathrm{P}$ & & & & & 0,80 & & 0,85 & & 0,87 & 0,79 & 0,80 & 0,81 & 0,82 & 0,80 & 0,83 & 0,82 & 0,84 \\
\hline $6 E P$ & 57,84 & 57,82 & 57,48 & 57,1 & 56,2 & 58,04 & 57,61 & 56,88 & 57,0 & 57,81 & 57,42 & 57,23 & 56,4 & 57,43 & 57,39 & 57,07 & 56,7 \\
\hline
\end{tabular}

Таблиця 3

Співвідношення основних кислот бродіння у зразках кукурудзи, \%

\begin{tabular}{|c|c|c|c|c|c|c|c|c|c|c|c|c|c|c|c|c|}
\hline \multirow{4}{*}{ № } & \multirow{2}{*}{\multicolumn{4}{|c|}{$\mathrm{pH}$}} & \multicolumn{12}{|c|}{ Співвідношення основних кислот } \\
\hline & & & & & \multicolumn{4}{|c|}{ Оцтова } & \multicolumn{4}{|c|}{ Масляна } & \multicolumn{4}{|c|}{ Молочна } \\
\hline & \multicolumn{16}{|c|}{ Доба } \\
\hline & 5 & 15 & 30 & 70 & 5 & 15 & 30 & 70 & 5 & 15 & 30 & 70 & 5 & 15 & 30 & 70 \\
\hline 1 & 5,64 & 5,60 & 5,46 & 5,38 & 8,71 & 9,95 & 10,31 & 23,09 & 0,11 & 0 & 0 & 0 & 91,17 & 90,04 & 89,68 & 76,90 \\
\hline 2 & 9,43 & 9,31 & 9,27 & 7,50 & 9,41 & 17,36 & 15,40 & 17,00 & 1,28 & 0 & 0 & 2,18 & 89,30 & 82,63 & 84,59 & 80,80 \\
\hline 3 & 5,68 & 5,53 & 5,45 & 5,40 & 9,04 & 11,22 & 15,25 & 12,91 & 0 & 0 & 0 & 0 & 90,95 & 88,77 & 84,74 & 87,08 \\
\hline 4 & 5,60 & 5,40 & 5,14 & 5,10 & 12,63 & 12,72 & 9,88 & 5,64 & 0 & 0 & 0 & 0 & 87,36 & 87,27 & 90,11 & 94,35 \\
\hline
\end{tabular}

Таблиця 4

Кількісний та груповий склад мікрофлори зразків консервованого зерна кукурудзи

\begin{tabular}{|c|c|c|c|c|c|c|c|c|c|c|c|c|c|c|c|}
\hline \multirow{3}{*}{ № } & \multicolumn{3}{|c|}{$\begin{array}{l}\text { МКБ, } \\
\text { КУО/Г }\end{array}$} & \multicolumn{3}{|c|}{$\begin{array}{c}\text { Bacillus, } \\
\text { КУО/Г }\end{array}$} & \multicolumn{3}{|c|}{$\begin{array}{c}\text { Гриби та дріжджі, } \\
\text { КУО/Г }\end{array}$} & \multicolumn{3}{|c|}{$\begin{array}{l}\text { Pseudomonas, } \\
\text { виділення газу }\end{array}$} & \multicolumn{3}{|c|}{$\begin{array}{c}\text { Clostridium, } \\
\text { КУО/г }\end{array}$} \\
\hline & \multicolumn{15}{|c|}{ Доба } \\
\hline & 15 & 30 & 70 & 15 & 30 & 70 & 15 & 30 & 70 & 15 & 30 & 70 & 15 & 30 & 70 \\
\hline 1 & $1,2 \cdot 10^{6}$ & $0,2 \cdot 10^{6}$ & $4,2 \cdot 10^{6}$ & $2 \cdot 10^{5}$ & $2 \cdot 10^{4}$ & $6,0 \cdot 10^{5}$ & $2 \cdot 10^{5}$ & $2 \cdot 10^{5}$ & $2,0 \cdot 10^{6}$ & - & - & & - & - & $3,4 \cdot 10^{7}$ \\
\hline 2 & $0,4 \cdot 10^{6}$ & $0,1 \cdot 10^{5}$ & $1,9 \cdot 10^{6}$ & $2 \cdot 10^{5}$ & $2 \cdot 10^{4}$ & $3,0 \cdot 10^{5}$ & $6 \cdot 10^{5}$ & $4 \cdot 10^{4}$ & $4,0 \cdot 10^{5}$ & - & - & & - & - & $2,7 \cdot 10^{7}$ \\
\hline 3 & $1 \cdot 10^{6}$ & $0,2 \cdot 10^{6}$ & $8,4 \cdot 10^{6}$ & $8 \cdot 10^{5}$ & $2 \cdot 10^{5}$ & $6,0 \cdot 10^{5}$ & $0,2 \cdot 10^{4}$ & $0,2 \cdot 10^{4}$ & $6,0 \cdot 10^{5}$ & - & - & & - & - & - \\
\hline 4 & $1,4 \cdot 10^{6}$ & $0,4 \cdot 10^{6}$ & $8,8 \cdot 10^{6}$ & $2 \cdot 10^{5}$ & $6 \cdot 10^{5}$ & $2,0 \cdot 10^{5}$ & $2 \cdot 10^{5}$ & $2 \cdot 10^{5}$ & $1,0 \cdot 10^{5}$ & - & - & & - & - & - \\
\hline
\end{tabular}

\section{Висновки}

1. Втрати сухої речовини як інтегрального показника поживності корму у зразках плющеного зерна кукурудзи, обробленого препаратами KT-L 18/1 та BAC у граничних дозах, становили відповідно 1,0 та 1,1 відн. $\%$.

2. Найнижча чисельність найбільш шкодочинних мікроміцетів була у варіантах з використанням препарату KT-L 18/1 у дозі 8 мл/кг.
3. Використання ВАС забезпечує пригнічення практично всіх досліджуваних мікроорганізмів, у т. ч. i найбільш корисних молочнокислих бактерій.

4. Означений пробіотичний препарат забезпечує збереженість поживних речовин зерна кукурудзи практично на рівні з хімічним консервантом завдяки активному розвитку молочнокислих мікроорганізмів.

Перспективи подальших досліджень. Для остаточних висновків доцільно провести апробацію даного препарату при заготівлі вологого плющеного зерна 
кукурудзи у виробничих умовах та в дослідах на тваринах.

\section{References}

Darmohray, L., Sedilo, G., \& Gutyj, B. (2017). Conceptual framework for the assessment of the nutritional and biological value of the plant Galega orientalis (Lam). Scientific Messenger of LNU of Veterinary Medicine and Biotechnologies, 19(79), 9-12. doi: $10.15421 /$ nvlvet7902.

Darmohray, L.M., \& Gonchar, M.V. (2015). Bioactivity of Pure Cultures of Bacteria and Yeast in the Background Action of the Water Extract of a Plant Galega orientalis (Lam) Research \& Reviews. Journal of Veterinary Sciences. 1(1), 82-85. http://www.rroij.com/openaccess/bioactivity-of-pure-cultures-of-bacteria-andyeast-in-the-background-action-of-the-water-extract-ofa-plant-galega-orientalis-lam.php?aid=59849.

Darmohray, L.M., Gutyj, B.V., \& Darmohray, O.O. (2018). Antimicrobic activity concept of water extract of plants Galega orientalis (Lam.). Scientific Messenger of Lviv National University of Veterinary Medicine and Biotechnologies, 20(87), 122-125. doi: $10.15421 /$ nvlvet8724.

Darmohray, L.M., Luchyn, I.S., \& Gutyj, B.V. (2017). Influence of feeding management on productive indicators of rabbits for intensive growing technology. Scientific Messenger LNUVMB, 19(79), 38-43. doi: 10.15421/nvlvet7908.

Derevyanko, S.V. (2009). Zastosuvannya mikrobnykh preparativ pry konservuvanni riznykh vydiv kormiv. Silskohospodarska mikrobiolohiya: TSNTEI, 9, 151157 (in Ukrainian).

Gutyj, B., Stybel, V., Darmohray, L., Lavryshyn, Y., Turko, I., Hachak, Y., Shcherbatyy, A., Bushueva, I., Parchenko, V., Kaplaushenko, A., \& Krushelnytska, O. (2017). Prooxidant-antioxidant balance in the organism of bulls (young cattle) after using cadmium load. Ukrainian Journal of Ecology, 7(4), 589-596. doi: 10.15421/2017_165.

Hlushko, L.T. (2006). Isnuyuchi ta novi tekhnolohichni pryyomy konservuvannya volohoho zerna kukurudzy. Kormy i kormovyrobnytstvo, 56, 122-131 (in Ukrainian).
Kashirskaja, M.D., Glinskij, S.A., Korobov, A.A., Kaljuzhnyj, I.I., Voronin, S.P., Gumenjuk, A.P., Savenkov, E.N., \& Stepanov, I.S. (2017). Konservirovanie vlazhnogo pljushhenogo zerna kukuruzy novym biologicheskim konservantom Kormoproizvodstvo, 12, 34-38. doi: 10.25685/ KRM.2017.37.9718 (in Russian).

Konyukhov, V.V., Romashko, S.S., \& Shkrabakh, O.A. (2004). Tekhnolohija pljushchenija i konservirovanija zerna - put $\mathrm{k}$ rentabelnosti proizvodstva. Kormoproyzvodstvo, 5, 29-32 (in Russian).

Kravchenko, N.O., Chumachenko, S.P., \& Perederiy, M.H. (2017). Konservuyucha zdatnist Bacillus subtilis pry zahotivli plyushchenoho volohoho zerna kukurudzy. Silskohospodarska mikrobiolohiya, 25, 57-62 (in Ukrainian).

Kulyk, M.F. (2006). Enerhooshchadni tekhnolohiyi kormiv - osnova konkurentozdatnoho tvarynnytstva. Vinnytsya: Teza (in Ukrainian).

Kvasnykov, E.Y., \& Nesterenko, O.A. (1975). Molochnokislye bakterii i puti ikh ispolzovanija. Moskva: Nauka (in Russian).

Nekrashevich, V.F., Afanas'eva, K.S., Borontova, M.A., Belov, A.E., \& Vorob'jova, I.V. (2017). Prigotovlenie i hranenie silosa $\mathrm{v}$ mjagkih vakuumirovannyh kontejnerah iz vozduhonepronicaemoj pljonki. Kormoproizvodstvo, 10, 44-47. doi: 10.25685/KRM. 2017.2017.9921 (in Russian).

Solyanyk, T.V., \& Hlaskovych, M.A. (2014). Mikrobiolohija. Mikrobiolohija kormov zhyvotnoho rastitel'noho proiskhozhdenija: kurs lektsiy. Horky: BHSKHA (in Russian).

Suslova, M.A. (2012). Vlyianie biolohycheskoho preparata na mikrobiolohicheskie pokazateli i khimicheskij sostav pliushchenoho zerna kukuruzy. Izvestija Orenburhskoho HAU, 34-1, 38-40 (in Russian).

Tepper, E.Z., Shyl'nikova, V.K., \& Pereverdeva, H.Y. (2004). Mikrobiolohija kormov. Praktykum po mikrobiolohii: uchebnoe posobie dlya vuzov. 5-e yzd., pererab i dop. Moskva: Drofa (in Russian).

Volkohon, V.V. (2015). Mikrobni preparaty v suchasnykh ahrarnykh tekhnolohiyakh. Naukovo-praktychni rekomendatsiyi. Chernihiv (in Ukrainian).

Vudmaska, V.Yu., \& Prylutskyy, P.P. (1975). Vyznachennya pozhyvnosti ta yakosti kormiv u hospodarstvi. Kyyiv: Urozhay (in Ukrainian). 